\title{
Methionine plus cystine to lysine ratio in diets for tambatinga fingerlings
}

\section{Relação da metionina mais cistina com a lisina em rações para alevinos de tambatinga}

\author{
Dayana da Conceição da $\operatorname{Costa}^{1 *}{ }^{\oplus}$, Marcos Antonio Delmondes Bomfim ${ }^{1} \oplus$, Felipe Barbosa Ribeiro ${ }^{1} \odot$,

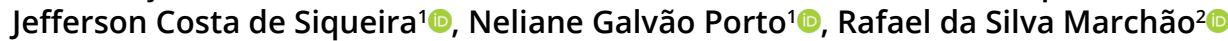

\author{
1Universidade Federal do Maranhão/UFMA, Chapadinha, MA, Brasil \\ ²Universidade Federal do Vale do São Francisco/UNIVASF, Petrolina, PE, Brasil \\ *Corresponding author: dayanacosta10@gmail.com
}

Received in July 18, 2021 and approved in September 17, 2021

\begin{abstract}
Among a variety of hybrids produced in Brazil, tambatinga is obtained from the crossing of a tambaqui female with a pirapitinga male. Although rapid weight gain in less time is an attractive characteristic from a commercial viewpoint, the information on its nutritional requirements, especially amino acid requirements, is limited. As corn and soybean meal-based diets available for fish contain deficient levels of essential amino acid methionine, our objective was to determine the digestible methionine plus cystine to lysine ratio in diets for tambatinga fingerlings. We used 900 fish with initial weights varying from $1.49 \pm 0.59$ to $4.14 \pm 1.70 \mathrm{~g}$, and they were fed six types of diets with different digestible methionine plus cystine to lysine ratios $(50,55,60,65,70$, and $75 \%$ ). Performance parameters such as food efficiency, body depositions of protein, fat, and ash, and nitrogen retention efficiency were evaluated. The increase of digestible methionine plus cystine to lysine ratio in the diet improved quadraticly the feed intake, consumption of digestible methionine plus cystine, weight gain, specific growth rate and feed conversion, protein deposition and body ash and retention efficiency nitrogen until the estimated ratios of $57 \%, 73 \%, 58 \%, 58 \%$ and $59 \%, 59 \%, 58 \%$ and $60 \%$, respectively; and reduced linearly the efficiency of using methionine plus cystine for the weight gain. On the other hand, body fat deposition was not affected. We concluded that the digestible methionine plus cystine: lysine ratio in the rations for tambatinga fingerlings is 59\%, for provide better performance and body protein deposition.
\end{abstract}

Index terms: Colossoma macropomum x Piaractus brachypomus; sulfur amino acids; ideal protein concept.

\begin{abstract}
RESUMO
Dentre uma variedade de híbridos produzidos no Brasil, tambatinga é um híbrido obtido do cruzamento da fêmea de tambaqui com um macho de pirapitinga. Embora o ganho de peso rápido em menos tempo seja uma característica atraente do ponto de vista comercial, as informações sobre suas necessidades nutricionais, especialmente as de aminoácidos, são limitadas. Como as dietas à base de milho e farelo de soja para peixes contêm níveis deficientes do aminoácido essencial metionina, nosso objetivo foi determinar a proporção de metionina digestível mais cistina para lisina em dietas para alevinos de tambatinga. Foram usados 900 peixes com pesos médios iniciais variando de 1,49 $\pm 0,59$ a 4,14 $\pm 1,70$ g alimentados com dietas contendo seis diferentes relações da metionina mais cistina com a lisina digestível (50, 55, 60, 65, 70 e 75\%). Foram avaliados parâmetros de desempenho, eficiência alimentar, deposições corporais de proteína, gordura e cinzas e eficiência de retenção de nitrogênio. O aumento da relação da metionina mais cistina:lisina digestível na dieta melhorou quadraticamente o consumo de ração, consumo de metionina digestível mais cistina, ganho de peso, taxa de crescimento específico e conversão alimentar, deposição de proteína e cinzas corporais e eficiência de retenção de nitrogênio até as proporções estimadas de 57\%,73\%, 58\%, 58\% e 59\%, 59\%, 58\% e 60\%, respectivamente; e reduziu linearmente a eficiência de metionina mais cistina para o ganho de peso. Por outro lado, a deposição de gordura corporal não foi afetada. Concluímos que a relação da metionina mais cistina:lisina digestível nas rações para alevinos de tambatinga é de 59\%, por proporcionar melhor desempenho e deposição de proteína corporal.
\end{abstract}

Termos para indexação: Colossoma macropomum x Piaractus brachypomus; aminoácidos sulfurados; proteína ideal.

\section{INTRODUCTION}

Tambatinga (Colossoma macropomum $\times$ Piaractus brachypomus) is the hybrid of a tambaqui female (Colossoma macropomum) and a pirapitinga male (Piaractus brachypomus), and has become distinguished among most hybrids produced in Brazil because it can gain one kilogram of weight in less than a year of cultivation and can easily adapt to an intensive system (Hashimoto et al., 2012). 
As dietary nutrients play an important role in the performance and body composition of animals, studies determining the protein and amino acid requirements of animals have been prioritized (National Research Council - NRC, 2011). Similar to other animals, fish require essential and non-essential amino acids for their metabolic requirements (Lanna et al., 2016; Silva et al., 2018).

For determining amino acid requirements, the ideal protein concept has been used for formulating experimental diets. The ideal protein concept refers to the appropriate balance of amino acids to meet the maintenance and growth requirements of animals without any deficiencies or excesses and is expressed as a percentage of a reference amino acid, the lysine (Furuya et al., 2005; Souza et al., 2019).

To determine the ratio of an essential amino acid to lysine, lysine levels are fixed at suboptimal values to ensure that it is the second limiting amino acid of basal diet. The other essential amino acids are fixed in quantities or amino acid:lysine ratios higher than the requirement values reported in the literature. In this sense, the requirement of the amino acid in question is influenced by the lysine level as the only limiting factor for maximum protein deposition (Boisen, 2003; Bomfim, 2013). Currently, this experimental protocol has been widely used in fish nutrition (Bomfim et al., 2008a; Bomfim et al., 2008c; Firmo et al., 2018; Souza et al., 2019).

Methionine is one of the most essential limiting amino acids in fish diets, based on corn and soybean meals. It plays an important role in chain elongation in protein synthesis and methyl group donation for diverse methylation reactions (Lewis, 2003; Bomfim et al., 2008a). The level of cystine, a non-essential amino acid, depends on the level of methionine because methionine is a precursor of cystine, which can interfere with the availability of methionine for a body's protein deposition (Lewis, 2003; Tang et al., 2009).

Considering the lack of information on amino acid requirements of tambatinga, the objective of our study was to determine the digestible methionine plus cystine to lysine ratio in the diets for the fingerlings of this species.

\section{MATERIAL AND METHODS}

\section{Facilities, experimental conditions, and design}

This study was performed at the Center for Agricultural and Environmental Sciences of the Federal University of Maranhão in the municipality of Chapadinha, Maranhão state, and according to the ethical standards established for the use of animals, after approval from the Ethics Committee on Animal Use at the Federal University of Maranhão (Protocol No. 23115.002771/2016-15).

Nine hundred tambatinga fingerlings with initial weights ranging from $1.49 \pm 0.59$ to $4.14 \pm 1.70$ were included in a randomized block design (50-day trial period in two blocks) with six replicates at a time per treatment (three replicates per block) and 25 fish per experimental unit.

Thirty-six polyethylene water tanks with a volume of $500 \mathrm{~L}$ and equipped with a closed water circulation system, an aeration system, and an individual drainage system were used. In the circulation system, effluents were transferred to a $1000 \mathrm{~L}$ polyethylene tank equipped with a filtering material (sand and gravel) before returning to the experimental units.

The supply water for the water tanks came from an artesian well. The water temperature was measured daily at 7:30 am and 5:30 pm by using a mercury bulb thermometer that was calibrated from 0 to $50^{\circ} \mathrm{C}$. The $\mathrm{pH}$, dissolved oxygen concentration, and ammonia level in the water were checked every seven days using a $\mathrm{pH}$ meter (Hanna), an oximeter (Hanna), and a commercial ammonia kit (LabconTest toxic ammonia), respectively.

The maximum and minimum water temperatures were $26.71 \pm 0.37^{\circ} \mathrm{C}$ and $24.50 \pm 0.58^{\circ} \mathrm{C}$, respectively. The concentration of dissolved oxygen in the water was $8.20 \pm 0.72 \mathrm{ppm}, \mathrm{pH}$ was $6.52 \pm 0.61$, and total ammonia level was $<1.00 \mathrm{ppm}$. The water quality parameters were based on the recommendations for breeding tambaqui as recommended by Gomes, Simões and Araújo-Lima (2010).

\section{Experimental diets}

The treatments consisted of a basal diet supplemented with five concentrations of DL-methionine (MetAmino ${ }^{\circledR} 99 \%$-Evonik), resulting in six isoenergetic, isocystinic, isocalcic, and isophosphoric diets containing different digestible methionine plus cystine to lysine ratios $(50,55,60,65,70$, and $75 \%)$ (Table 1$)$.

To determine the digestible methionine plus cystine to lysine ratio, the content of digestible lysine used in the experimental diets was fixed at a suboptimal level $(1.45 \%)$ based on the requirement $(1.78 \%)$ determined by Silva et al. (2018) for tambaqui. Lysine was considered as the second limiting amino acid in the basal diet, according to the methodological procedure recommended by Boisen (2003). The ratio of the other essential amino acids to lysine was maintained at least three points above the estimated on the basis of the proposal by the National Research Council, NRC (2011) for Nile tilapia. 
Table 1: Composition chemistry and percentage of the experimental diets, based on the concept of the ideal protein (natural matter).

\begin{tabular}{|c|c|c|c|c|c|c|}
\hline \multirow{2}{*}{ Ingredients (\%) } & \multicolumn{6}{|c|}{ Digestible methionine plus cystine to lysine ratio (\%) } \\
\hline & 50.0 & 55.0 & 60.0 & 65.0 & 70.0 & 75.0 \\
\hline Soybean meal & 52.501 & 52.501 & 52.501 & 52.501 & 52.501 & 52.501 \\
\hline Corn & 37.171 & 37.171 & 37.171 & 37.171 & 37.171 & 37.171 \\
\hline Corn starch & 1.115 & 1.114 & 1.113 & 1.113 & 1.112 & 1.111 \\
\hline Soybean oil & 4.492 & 4.461 & 4.431 & 4.401 & 4.370 & 4.340 \\
\hline DL-Methionine & 0.000 & 0.074 & 0.148 & 0.221 & 0.295 & 0.369 \\
\hline L-Threonine & 0.239 & 0.239 & 0.239 & 0.239 & 0.239 & 0.239 \\
\hline L-Tryptophan & 0.037 & 0.037 & 0.037 & 0.037 & 0.037 & 0.037 \\
\hline L-Alanine & 0.214 & 0.171 & 0.128 & 0.086 & 0.043 & 0.000 \\
\hline Dicalcium phosphate & 3.153 & 3.153 & 3.153 & 3.153 & 3.153 & 3.153 \\
\hline Vitamin and mineral premix ${ }^{1}$ & 0.500 & 0.500 & 0.500 & 0.500 & 0.500 & 0.500 \\
\hline Vitamin $C^{2}$ & 0.050 & 0.050 & 0.050 & 0.050 & 0.050 & 0.050 \\
\hline Salt & 0.509 & 0.509 & 0.509 & 0.509 & 0.509 & 0.509 \\
\hline Antioxidant (BHT) & 0.020 & 0.020 & 0.020 & 0.020 & 0.020 & 0.020 \\
\hline \multicolumn{7}{|c|}{ Calculated composition ${ }^{3}$} \\
\hline Crude protein (\%) & 27.11 & 27.11 & 27.11 & 27.11 & 27.11 & 27.11 \\
\hline Digestible protein $(\%)^{4}$ & 24.69 & 24.69 & 24.69 & 24.69 & 24.69 & 24.69 \\
\hline Digestible energy $\left(\mathrm{kcal} \mathrm{kg}^{-1}\right)^{4}$ & 3000.00 & 3000.00 & 3000.00 & 3000.00 & 3000.00 & 3000.00 \\
\hline Crude fiber (\%) & 3.43 & 3.43 & 3.43 & 3.43 & 3.43 & 3.43 \\
\hline Total calcium (\%) & 0.91 & 0.91 & 0.91 & 0.91 & 0.91 & 0.91 \\
\hline Phosphorus available (\%) & 0.70 & 0.70 & 0.70 & 0.70 & 0.70 & 0.70 \\
\hline Digestible lysine $(\%)^{5}$ & 1.450 & 1.450 & 1.450 & 1.450 & 1.450 & 1.450 \\
\hline Digestible met + Cys $(\%)^{5}$ & 0.725 & 0.798 & 0.870 & 0.943 & 1.015 & 1.088 \\
\hline Digestible threonine $(\%)^{5}$ & 1.189 & 1.189 & 1.189 & 1.189 & 1.189 & 1.189 \\
\hline Digestible tryptophan (\%) & 0.363 & 0.363 & 0.363 & 0.363 & 0.363 & 0.363 \\
\hline Ratio met. + cys. Dig./DE (g Mcal-1) & 0.242 & 0.266 & 0.290 & 0.314 & 0.338 & 0.363 \\
\hline Digestible met+cys/lysine ratio & 50.0 & 55.0 & 60.0 & 65.0 & 70.0 & 75.0 \\
\hline Digestible threonine/lysine ratio & 82.0 & 82.0 & 82.0 & 82.0 & 82.0 & 82.0 \\
\hline Digestible tryptophan/lysine ratio & 25.0 & 25.0 & 25.0 & 25.0 & 25.0 & 25.0 \\
\hline
\end{tabular}

${ }^{1}$ Vitamin and mineral premix $\left(5 \mathrm{~kg} \mathrm{t}^{-1}\right)$, with guarantee levels per kilogram of the product: Vit. A, 1,200,000 Ul; Vit. D3, 200,000 Ul; Vit. E, 1,200 mg; Vit. K3, 2,400 mg; Vit. B1, 4,800 mg; Vit.B2, 4,800 mg; Vit.B6, 4,800 mg; Vit.B12, 4,800 mg; Vit.C, 48 g; folic acid, 1.200 mg; Ca pantothenate, 12.000 mg; Vit. C, 48.000 mg; biotin, 48 mg; choline chloride, 108 g; niacin, 24.000 mg; Fe, 50.000 mg; Cu, 3.000 mg; Mn, 20.000 mg; Zn, 30.000 mg; I, 100 mg; Co, 10 mg; Se, 100 m; ${ }^{2}$ Vit. C: Calcium L-ascorbic acid 2-monophosphate, $42 \%$ of active principle; ${ }^{3}$ Based on the values proposed by Rostagno et al. (2011); ${ }^{4}$ Based on the digestibility coefficients for the corn starch, corn, soybean meal and soybean oil proposed by Furuya et al. (2010) for the Nile tilapia; ${ }^{5}$ Based on the digestibility coefficients for the industrial amino acid proposed by Rostagno et al. (2011) and the amino acids and availability of phosphorus of corn and soybean meal proposed by Furuya et al. (2010).

The levels of total and digestible amino acids in the corn and soybean meals were obtained by performing an aminogram at the CBO laboratory (Valinhos-SP) (Table 2). 
Table 2: Composition in total (TAA) and digestible (DAA) amino acids of corn and soybean meal used in experimental diets.

\begin{tabular}{|c|c|c|c|c|}
\hline \multirow{2}{*}{$(\%)$} & \multicolumn{2}{|c|}{ Corn (\%) } & \multicolumn{2}{|c|}{ Soybean meal (\%) } \\
\hline & $\mathrm{TAA}^{1}$ & $\mathrm{DAA}^{2}$ & TAA $^{1}$ & $\mathrm{DAA}^{2}$ \\
\hline Lysine & 0.30 & 0.27 & 2.94 & 2.77 \\
\hline Methionine & 0.17 & 0.16 & 0.59 & 0.56 \\
\hline Methionine + cystine & 0.30 & 0.27 & 1.27 & 1.18 \\
\hline Threonine & 0.34 & 0.33 & 1.91 & 1.87 \\
\hline Tryptophan & 0.04 & 0.03 & 0.78 & 0.73 \\
\hline Arginine & 0.44 & 0.42 & 3.48 & 3.45 \\
\hline Valine & 0.40 & 0.39 & 2.27 & 2.20 \\
\hline Alanine & 0.61 & 0.59 & 2.11 & 2,05 \\
\hline Isoleucine & 0.30 & 0.29 & 2.27 & 2.20 \\
\hline Leucine & 0.91 & 0.89 & 3.47 & 3.37 \\
\hline Histidine & 0.25 & 0.23 & 1.28 & 1.22 \\
\hline Phenylalanine & 0.38 & 0.37 & 2.44 & 2.39 \\
\hline Phenylalanine + tyrosine & 0.70 & 0.69 & 4.22 & 4.14 \\
\hline Crude protein & \multicolumn{2}{|c|}{8.52} & \multicolumn{2}{|c|}{45.60} \\
\hline
\end{tabular}

${ }^{1}$ Total amino acids, determined by high performance liquid chromatography by the laboratory CBO - Valinhos, SP. ${ }^{2}$ Digestible amino acids, calculated based on digestibility coefficients proposed by Nascimento et al. (2020) for tambaqui.

The ingredients of the experimental diets were mixed, moistened with water, heated to about $50^{\circ} \mathrm{C}$, and pelleted using a meat grinder (CAF Meat grinder; model $98 \mathrm{STI})$. Then, the diets were dried in an oven with forced air circulation for $24 \mathrm{~h}$. After drying, they were crushed and sieved to obtain pellets in different diameters.

The diets were offered ad libitum daily in the form of six meals ( $8 \mathrm{am}, 10 \mathrm{am}, 12 \mathrm{pm}, 2 \mathrm{pm}, 4 \mathrm{pm}$, and $6 \mathrm{pm}$ ) in small quantities, with successive repass until apparent satiety; thus, over-and under-feeding were avoided. The boxes were cleaned daily by siphoning, always after checking the water temperature.

\section{Carcass preparation and analysis}

At the beginning of the experiment, a sample of around $50 \mathrm{~g}$ of fish was desensitized and euthanized with benzocaine overdose $\left(250 \mathrm{mg} \mathrm{L}^{-1}\right)$ and frozen to determine the initial body composition. At the end of the experiment, after a 24-h fast, the fish were weighed, desensitized, and euthanized with benzocaine overdose $\left(250 \mathrm{mg} \mathrm{L}^{-1}\right)$ and frozen in the experimental unit to determine the final body composition.
After freezing, the fish samples (initial and final) were dried in an oven with forced air circulation, predegreased, ground in a Willye mill (model TE-650), and placed in containers for laboratory analysis. The laboratory analyses were performed at the Animal Nutrition Laboratory of the Center for Agricultural and Environmental Sciences at the Federal University of Maranhão - UFMA according to the Association of Official Analytical Chemists, AOAC (2019).

\section{Evaluated variables}

We evaluated the feed intake (FI), digestible methionine plus cystine intake (DMCI), weight gain (WG), specific growth rate (SGR), feed conversion rate (FCR), and methionine plus cystine efficiency for weight gain (MCEG). Based on body composition (levels of proteins, fats, and body ash), daily body protein deposition (BPD), body fat deposition (BFD), body ash deposition (BAD), and nitrogen retention efficiency (NRE) of fish were evaluated according to the equations given below:

$$
\begin{aligned}
\mathrm{FI}(\mathrm{g})= & \text { feed consumed during the } \\
& \text { experimental period - any leftovers }
\end{aligned}
$$


$\mathrm{WG}(\mathrm{g})=$ final mean weight - initial mean weight

DMCI $(\mathrm{mg})=\frac{[\text { feed intake }(\mathrm{mg}) \times \text { content of digestible methionine plus cystine in the diet }(\%)]}{100}$

$\operatorname{SGR}\left(\%\right.$ day $\left.^{-1}\right)=\frac{[(\text { natural logarithm of final weight }(\mathrm{g})-\text { natural logarithm of initial weight }(\mathrm{g})) \mathrm{x} 100]}{\text { experimental period (days) }}$

$\operatorname{FCR}\left(\mathrm{g} \mathrm{g}^{-1}\right)=\frac{\text { feed intake }(\mathrm{g})}{\text { weight gain }(\mathrm{g})}$

$\operatorname{MCEG}\left(\mathrm{g} \mathrm{g}^{-1}\right)=\frac{\text { weight of gain }(\mathrm{g})}{\text { digestible methionine plus cystine intake }(\mathrm{g})}$

$\operatorname{BPD}\left(\mathrm{mg} \mathrm{day}^{-1}\right)=\frac{\{[(\% \text { final body protein } \mathrm{x} \text { final weight }(\mathrm{mg}))-(\% \text { initial body protein } \mathrm{x} \text { initial weight }(\mathrm{mg}))] / 100\}}{\text { experimental period (days) }}$

$\operatorname{BFD}\left(\mathrm{mg} \mathrm{day}^{-1}\right)=\frac{\{[(\% \text { final body fat } \mathrm{x} \text { final weight }(\mathrm{mg}))-(\% \text { Initial body fat } \mathrm{x} \text { initial weight }(\mathrm{mg}))] / 100\}}{\text { experimental period (days) }}$

$\operatorname{BAD}(\operatorname{mg}$ day -1$)=\frac{\{[(\% \text { final body ash } \mathrm{x} \text { final weight }(\mathrm{mg}))-(\% \text { Initial body ash } \mathrm{x} \text { initial weight }(\mathrm{mg}))] / 100\}}{\text { experimental period (days) }}$

$\operatorname{NRE}(\%)=\frac{[(\% \text { final body } \mathrm{N} x \text { final weight }(\mathrm{g}))-(\% \text { Initial body } \mathrm{N} x \text { initial weight }(\mathrm{g}))]}{(\text { feed consumption }(\mathrm{g}) \mathrm{x} \text { content of } \mathrm{N} \text { of } \operatorname{diet}(\%)) / 100}$

\section{Statistical analyses}

The means \pm standard errors were calculated using Excel from the Microsoft Office 10 (Microsoft $\left.{ }^{\circledR}\right)$ package. The data were subjected to the Shapiro-Wilk and Levene tests to test normality and homoscedasticity. Further, unidirectional analysis of variance (ANOVA) was performed. For the variables that showed the effects of the digestible methionine plus cystine to lysine by ANOVA, regression analyses were performed using linear and quadratic models. To choose the best fit model, the $P$-value (significance) and $\mathrm{R}^{2}$ (SQ of the model/SQ of the treatment) were taken into account. Statistical analyses were performed using the SAEG 9.1 (Universidade Federal de Viçosa - UFV, 2007) software by considering a $P$-value of $<0.05$ as a level of significance.

\section{RESULTS AND DISCUSSION}

The treatments had a significant effect $(P<0.05)$ on all variables of the performance and feed efficiency. The increase in the digestible methionine plus cystine to lysine ratio resulted in a quadratic increase in $\mathrm{FI}(P<0.05)$, DMCI $(P<0.01)$, WG $(P<0.05)$, and SGR $(P<0.05)$ up to the estimated levels of $57,73,58$, and $58 \%$ of the digestible methionine plus cystine to lysine ratio, respectively.

The average growth rate of $4.7 \%$ per day obtained in the fish fed with the best-estimated ratio (58\%) was lower than the average growth rates of $5.69 \%, 5.87 \%$, and $6.7 \%$ reported by Araripe et al. (2011a), Araripe et al. (2011b), and Bomfim et al. (2021), respectively. All these studies used the same animal species. Despite this variation in the growth rates and usual requirement ratio of $32 \%$ for most fish in this range, the diets supplemented with free amino acids 
along with a lower amount of crude proteins were sufficient to enhance the performance of the animals (Bomfim et al., 2008c). Further, the sanitary conditions and management used in the experiment positively affected the performance enhancement in the animals (Bomfim et al., 2008c).

The dietary variation in the digestible methionine plus cystine to lysine ratios showed a quadratic behavior $(P<0.05)$ in the FCR; thus, improving this variable up to the ratio of $59 \%$. On the other hand, there was a linear reduction $(P<0.01)$ in the efficiency of using methionine plus cystine for WG with the increase in the digestible methionine to lysine ratio (Tables 3 and 4, Figure 1).

The results indicated that the best amino acid balance provided by the adjustment in the digestible methionine plus cystine to lysine ratio resulted in higher FI (energy and other nutrients) and consequently resulted in greater WG and SGR, increasing the proportion of nutrients for body growth processes in relation to maintenance (NRC, 2011) up to at least a ratio of 58\%.

These results differ from Souza et al. (2019), who evaluated effects of diet treatments with different digestible methionine plus cystine to lysine ratios $(50,55,60,65,70$, and $75 \%$ ) for tambaqui juveniles and did not report any considerable effect of the diet treatments on FI and WG of animals. Probably, the lack of effects may be related to the higher variation coefficient observed for these variables. On the other hand, the ratio obtained for the SGR (58\%) in our study was lower than the ratio of $64.4 \%$ estimated by Souza et al.
A study performed using Nile tilapia reported higher values than those obtained in this study. Bomfim et al. (2008a), evaluated different digestible methionine plus cystine to lysine ratios $(59.5,63.5,67.5,71.5$, and $75.5 \%)$ for Nile tilapia fingerlings and did not verify the effect of sulfur amino acids on the performance and feed efficiency, concluding by the lowest ratio evaluated. Based on individual requirement values, the NRC (2011) recommends the $62.5 \%$ digestible methionine plus cystine to lysine ratio for juvenile Nile tilapia.

In relation to the FCR, the best feed balance achieved by the increase in the digestible methionine plus cystine to lysine ratio also affected the nutrient use efficiency, preferably protein deposition, since the lean tissue deposition (protein) per unit of WG is more efficient than BFD due to the addition of more water (Souza et al., 2019). Souza et al. (2019) determined the digestible methionine plus cystine to lysine ratio higher $(64.8 \%)$ than that obtained in this research to optimize the feed conversion rate of tambaqui juveniles.

On the other hand, the reduction in the efficient use of MCEG in the fish might be related to other metabolic pathways of sulfur amino acids in addition to the BPD, since methionine acted as an important donor of methyl groups for diverse methylation reactions (Lewis, 2003; Wang et al., 2016). Although methionine plus cystine in lower dietary levels were used by the fish more efficiently for WG, its supplementation was necessary up to a ratio of $59 \%$ to ensure optimized performance (Bomfim et al., 2008a).

Table 3: Feed intake (FI), digestible methionine plus cystine intake (DMCI), weight gain (WG), specific growth rate (SGR), feed conversion rate (FCR), digestible methionine plus cystine efficiency for weight gain (MCEG) of tambatinga fingerlings, and summary of variance analysis in function to the digestible methionine plus cystine to lysine ratio in the diet.

\begin{tabular}{ccccccc}
\hline $\begin{array}{c}\text { Digestible methionine plus } \\
\text { cystine to lysine ratio } \\
(\%)\end{array}$ & $\begin{array}{c}\mathrm{FI} \\
(\mathrm{g})\end{array}$ & $\begin{array}{c}\mathrm{DMCl} \\
(\mathrm{mg})\end{array}$ & $\begin{array}{c}\text { WG } \\
(\mathrm{g})\end{array}$ & $\begin{array}{c}\text { SGR } \\
\left(\% \mathrm{dia}^{-1}\right)\end{array}$ & $\begin{array}{c}\text { FCR } \\
\left(\mathrm{g} \mathrm{g}^{-1}\right)\end{array}$ & $\begin{array}{c}\text { MCEG } \\
\left(\mathrm{g} \mathrm{g}^{-1}\right)\end{array}$ \\
\cline { 2 - 7 } 50 & 27.60 & 200.17 & 21.02 & 4.50 & 1.37 & 102.47 \\
55 & 30.12 & 240.33 & 23.28 & 4.65 & 1.38 & 96.31 \\
60 & 29.73 & 258.50 & 23.42 & 4.70 & 1.32 & 90.99 \\
65 & 26.41 & 249.17 & 19.30 & 4.36 & 1.40 & 77.63 \\
70 & 27.14 & 275.50 & 21.08 & 4.51 & 1.34 & 76.79 \\
75 & 25.19 & 273.83 & 16.64 & 4.11 & 1.56 & 60.83 \\
Linear p-value & $<0.001$ & $<0.001$ & 0.005 & 0.003 & 0.040 & $<0.001$ \\
Quadratic p-value & 0.012 & 0.005 & 0.031 & 0.016 & 0.020 & 0.999 \\
CV (\%) & 6.47 & 6.15 & 15.30 & 5.56 & 8.57 & 12.33 \\
\hline
\end{tabular}

$\mathrm{CV}$ - Coefficient of variation. 
Table 4: Adjusted regression equations, determination coefficients and requirement values for the variables feed intake (FI), digestible methionine plus cystine intake (CDMI), weight gain (WG), specific growth rate (SGR), feed conversion rate (FCR), digestible methionine plus cystine efficiency for weight gain (MCEG) of tambatinga fingerling in function to the digestible methionine plus cystine to lysine ratio in the diet.

\begin{tabular}{|c|c|c|c|c|}
\hline Variable & Model & Equation & $\mathrm{R}^{2}$ & Ratio (\%) \\
\hline $\mathrm{Fl}(\mathrm{g})$ & Linear & $\hat{Y}=-0.138956 x+36.3814$ & 0.46 & ----- \\
\hline $\mathrm{Fl}(\mathrm{g})$ & Quadratic & $\hat{Y}=-0.0127791 x^{2}+1.45843 x-12.605$ & 0.67 & 57 \\
\hline $\mathrm{DMCl}(\mathrm{mg})$ & Linear & $\hat{Y}=2.65429 x+101.923$ & 0.80 & ----- \\
\hline $\mathrm{DMCl}(\mathrm{mg})$ & Quadratic & $\hat{Y}=-0.126065 x^{2}+18.4123 x-399.556$ & 0.89 & 73 \\
\hline WG (g) & Linear & $\hat{Y}=-0.186314 x+32.4321$ & 0.46 & ----- \\
\hline WG (g) & Quadratic & $\hat{Y}=-0.0192343 x^{2}+2.21798 x-41.2994$ & 0.73 & 58 \\
\hline $\operatorname{SGR}\left(\% \mathrm{dia}^{-1}\right)$ & Linear & $\hat{Y}=-0.015781 x+1.0799$ & 0.46 & ----- \\
\hline $\operatorname{SGR}\left(\% \mathrm{dia}^{-1}\right)$ & Quadratic & $\hat{Y}=-0.00170821 x^{2}+0.197745 x-1.08987$ & 0.75 & 58 \\
\hline FCR $\left(\mathrm{g} \mathrm{g}^{-1}\right)$ & Linear & $\hat{Y}=0.00500952 x+5.45825$ & 0.29 & ----- \\
\hline $\mathrm{FCR}\left(\mathrm{g} \mathrm{g}^{-1}\right)$ & Quadratic & $\hat{Y}=0.000785658 x^{2}-0.0931977 x+4.09159$ & 0.68 & 59 \\
\hline MCEG $\left(\mathrm{g} \mathrm{g}^{-1}\right)$ & Linear & $\hat{Y}=-1.60072 x+184.212$ & 0.96 & ---- \\
\hline
\end{tabular}

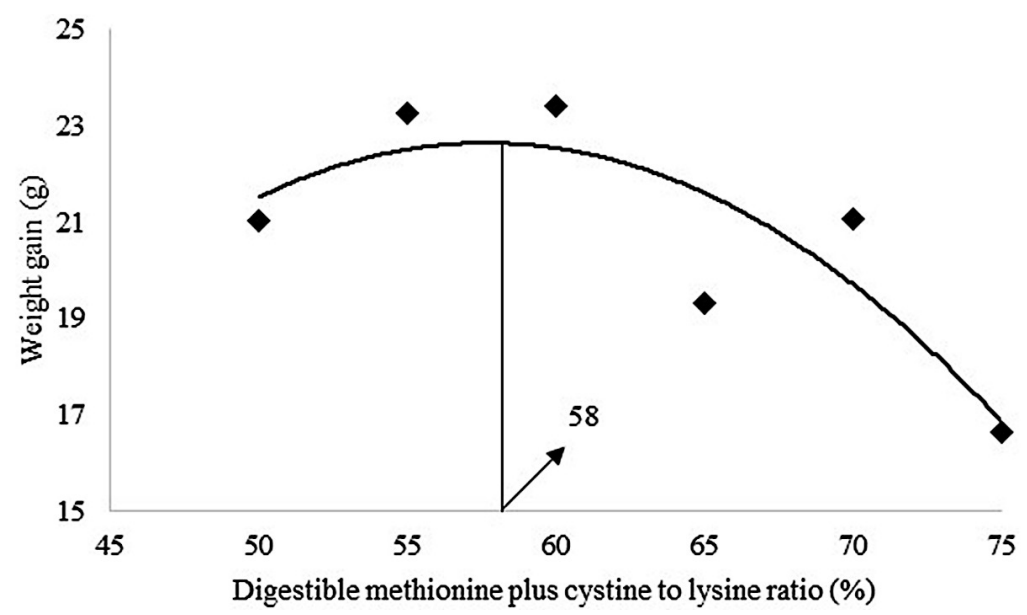

Figure 1: Weight gain of tambatinga fingerlings in function to the digestible methionine plus cystine to lysine ratio in the diet.

The dietary variation in the digestible methionine plus cystine to lysine ratios showed a quadratic behavior $(\mathrm{P}<0.05)$ in $\mathrm{BPC}, \mathrm{BAC}$ and NRE, improving these variables up to the ratios of 59,58 and $60 \%$, respectively. (Tables 5 and 6, Figure 2). The BFD was not affected by the treatments $(P>0.05)$.

The daily increase in the BPD indicated that the adjustment in the biological value of dietary protein, provided by the increase in the digestible methionine plus cystine to lysine ratio up to $59 \%$, supported the efficient conversion of dietary protein into fish muscle proteins, corroborating the results observed in the performance and feed efficiency variables (Silva et al. 2018).

These results differed from those reported by Bomfim et al. (2008a) and Souza et al. (2019), who found no effect of the digestible methionine plus cystine 
to lysine ratios on BPD, BFD, and NRE. The hypothesis for both studies was not related to the variation in these variables and was maybe related to meeting the dietary requirement at the lowest evaluated level (Bomfim et al., 2008a), and the highest coefficient of variation observed in these variables (Souza et al., 2019 ).

The no variation in the BFD might be related to the fact that the experimental diets are isoproteic, since the energy expenditure did not vary significantly to metabolize amino acids due to the use of diets with similar energy to protein ratios. On the other hand, the increase in BAD might be related to the formation of bone tissues that are important for the support of muscle tissues (Sousa et al., 2019).
The increase in nitrogen retention efficiency in function to digestible methionine plus cystine to lysine ratio up to $60 \%$, corroborates the result obtained for the body protein deposition, and demonstrates that the balance of the amino acid profile provided better dietary protein efficiency for depositing lean tissue (Firmo et al., 2018).

The digestible methionine plus cystine to lysine ratio varies between the results found in the literature, where most of the research was performed using Nile tilapia. According to the NRC (2011), a ratio of $62.5 \%$ is recommended for juvenile Nile tilapia. The Brazilian Tables for Tilapia Nutrition (Furuya et al., 2010) and Bomfim et al. (2008a) recommend similar values ( $60 \%$ and $59.5 \%$, respectively). For tambaqui juveniles, Souza et al. (2019) recommend the ratio of $64.8 \%$.

Table 5: Body protein (BPC), fat (BFD) and ashes (BAD) depositions and nitrogen retention efficiency (NRE) of tambatinga fingerlings and summary of variance analysis in function to the digestible methionine plus cystine to lysine ratio in the diet.

\begin{tabular}{ccccc}
\hline \multirow{2}{*}{$\begin{array}{c}\text { Digestible methionine plus } \\
\text { cystine to lysine ratio } \\
(\%)\end{array}$} & BPD $\left(\mathrm{mg} \mathrm{day}^{-1}\right)$ & BFD $\left(\mathrm{mg} \mathrm{day}^{-1}\right)$ & BAD $\left(\mathrm{mg} \mathrm{day}^{-1}\right)$ & NRE $(\%)$ \\
\cline { 2 - 5 } & 43.19 & 36.47 & 11.18 & 28.49 \\
50 & 57.07 & 29.42 & 14.70 & 34.66 \\
60 & 58.12 & 25.49 & 15.23 & 36.40 \\
65 & 39.89 & 32.33 & 10.23 & 28.04 \\
70 & 43.11 & 35.07 & 10.69 & 29.61 \\
75 & 34.25 & 27.03 & 8.70 & 25.17 \\
Linear p-value & 0.019 & 0.999 & 0.004 & 0.082 \\
Quadratic p-value & 0.030 & 0.999 & 0.011 & 0.036 \\
CV (\%) & 26.80 & 29.43 & 23.14 & 21.45 \\
\hline
\end{tabular}

CV - Coefficient of variation.

Table 6: Adjusted regression equations, determination coefficients and requirement values for the variables body protein (BPC) and ashes (BAD) depositions and nitrogen retention efficiency (NRE) of tambatinga fingerlings in function to the digestible methionine plus cystine to lysine ratio in the diet.

\begin{tabular}{|c|c|c|c|c|}
\hline Variable & Model & Equation & $\mathrm{R}^{2}$ & Ratio (\%) \\
\hline BPD (mg day $\left.{ }^{-1}\right)$ & Linear & $\hat{Y}=-0.598905 x+83.3707$ & 0.34 & $\begin{array}{c}---- \\
---\end{array}$ \\
\hline $\mathrm{BPD}\left(\mathrm{mg}\right.$ day $\left.^{-1}\right)$ & Quadratic & $\hat{Y}=-0.0749698 x^{2}+8.77234 x-204.014$ & 0.62 & 59 \\
\hline $\operatorname{BAD}\left(\mathrm{mg}\right.$ day $\left.^{-1}\right)$ & Linear & $\hat{Y}=-0.16799 x+22.2869$ & 0.36 & ----- \\
\hline $\mathrm{BAD}\left(\mathrm{mg}\right.$ day $\left.^{-1}\right)$ & Quadratic & $\hat{Y}=-0.01987 x^{2}+2.31576 x-53.8814$ & 0.64 & 58 \\
\hline NRE (\%) & Linear & $\hat{Y}=-15.8035 x+44.7217$ & 0.25 & ---- \\
\hline NRE (\%) & Quadratic & $\hat{Y}=-3.83806 x^{2}+4.56847 x-102.41$ & 0.63 & 60 \\
\hline
\end{tabular}




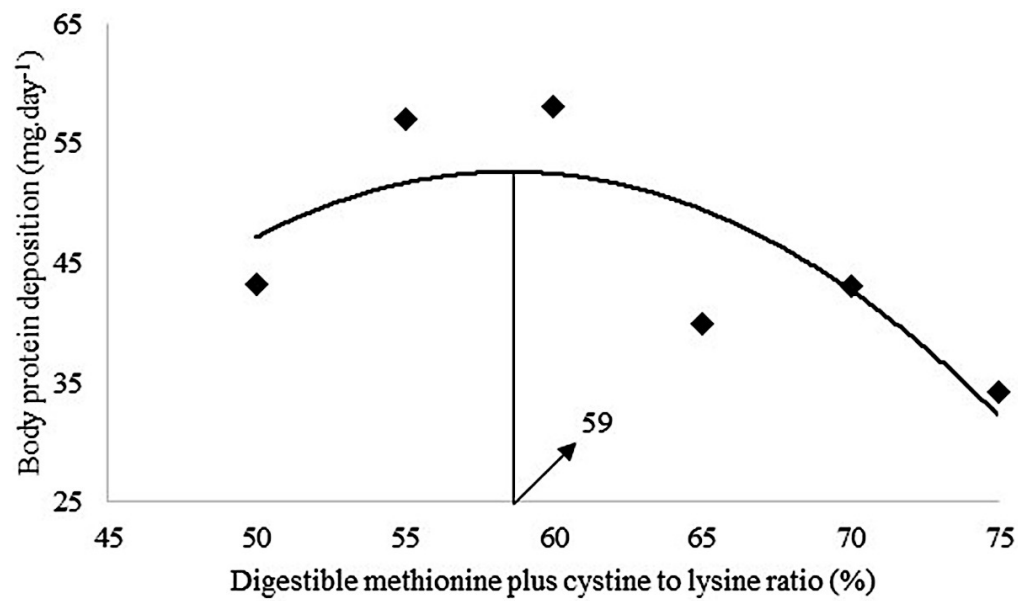

Figure 2: Body protein deposition of tambatinga fingerlings with regard to the digestible methionine plus cystine to lysine ratio in the diet.

The variations between the different results could be attributed to the criterion for choosing the variable (performance or tissue deposition). For determining the requirement of essential amino acids by the dose-response method, the most used criterions WG. However, the BPD is a more objective variable because it only considered lean tissue deposition (Silva et al., 2018).

The results obtained in our study will serve as a basis for formulating diets for tambatinga, since using the nutritional requirements of their parents may not ensure better feed efficiency and protein tissue deposition due to their different growth rates, composition, and body yield, indicating that nutritional requirements can be different.

\section{CONCLUSION}

The digestible methionine plus cystine to lysine ratio in diets for tambatinga fingerlings is $59.0 \%$, as it improves the performance variables (weight gain and feed conversion ratio) and increases the body protein deposition for the formation of lean tissue.

\section{AUTHOR CONTRIBUTION}

Conceptual idea: Costa, DC; Bomfim, MAD; Ribeiro, FB; Siqueira, JC; Methodology design: Costa, DC; Bomfim, MAD; Ribeiro, FB; Marchão, RS; Data collect: Costa, DC; Porto, NG; Marchão, RS; Data analysis and interpretation: Siqueira, JC; Costa, DC; Bomfim, MAD; Writing and editing: Costa, DC; Bomfim, MAD; Ribeiro, FB; Siqueira, JC; Porto, NG; Marchão, RS.

\section{ACKNOWLEDGMENTS}

To the Fundação de Amparo à Pesquisa e ao Desenvolvimento Científico e Tecnológico do Maranhão (FAPEMA) for project financing. This study was financed in part by the Coordenação de Aperfeiçoamento de Pessoal de Nível Superior-Brasil (CAPES)-Finance Code 001.

\section{REFERENCES}

ALENCAR ARARIPE, M. N. B. et al. Redução da proteína bruta com suplementação de aminoácidos em rações para alevinos de tambatinga. Revista Brasileira de Zootecnia, 40(9):1845-1850, 2011a.

ALENCAR ARARIPE, M. N. B. et al. Relação treonina:lisina para alevinos de tambatinga (Colossoma macropomum x Piaractus brachipomus). Boletim do Instituto de Pesca, 37(4):393-400, $2011 \mathrm{~b}$.

ASSOCIATION OF OFFICIAL ANALYTICAL CHEMISTSINTERNATIONAL - AOAC. Official methods of Analysis. 21ed. Rockville, MD.: AOAC, 2019. 3390p.

BOISEN, S. Ideal dietary amino acid profiles for pigs In: D'MELLO, J. P. D. (Ed.) Amino acid in farm animal nutrition. Wallingford: CAB International, 2.ed., p.157-168, 2003.

BOMFIM, M. A. D. Estratégias nutricionais para redução das excreções de nitrogênio e fósforo nos sistemas de produção de peixes no Nordeste: Sustentabilidade ambiental e aumento da produtividade. Revista Científica de Produção Animal, 12(2):122-140, 2013. 
BOMFIM, M. A. D. et al. Digestible threonine requeriment in diets for tambatinga (Colossoma macropomum x Piaractus brachypomus) fingerlings. Ciência e Agrotecnologia, 45:e023520, 2021.

BOMFIM, M. A. D. et al. Exigência de metionina mais cistina, com base no conceito de proteína ideal, em rações para alevinos de tilápia-do-nilo. Revista Brasileira de Zootecnia, 37(5):783-790, 2008a.

BOMFIM, M. A. D. et al. Exigência de treonina, com base no conceito de proteína ideal, de alevinos de tilápia-do-nilo. Revista Brasileira de Zootecnia, 37(12):2077-2084, 2008c.

FIRMO, D. S. et al. Threonine to lysine ratio in diets of tambaqui juveniles (Colossoma macropomum). Semina: Ciências Agrárias, 39(5):2169-2180, 2018.

FURUYA, W. M. et al. Aplicação do conceito de proteína ideal para redução dos níveis de proteína em dietas para tilapia-do-Nilo (Oreochromis niloticus). Revista Brasileira de Zootecnia, 34(5):1433-1441, 2005.

FURUYA, W. M. et al. Tabelas brasileiras para nutrição de tilápias. Toledo: GFM, 2010. 100p.

GOMES, L. C.; SIMÕES, L. N.; ARAÚJO-LIMA, C. A. R. M. Tambaqui (Colossoma macropomum). In: BALDISSSEROTTO, B. Espécies nativas para piscicultura no Brasil. 2.ed. Santa Maria: UFSM, p.175-204, 2010.

HASHIMOTO, D. T. et al. Interspecific fish hybrids in Brazil: Management of genetic resources for sustainable use. Reviews in Aquaculture, 4(2):108-118, 2012.

LANNA, E. A. T. et al. Feeding frequency of nile tilapia fed rations supplemented with amino acids. Revista Caatinga, 29(2):458-464, 2016.
LEWIS, A. J. Methionine - Cystine relationships in pig nutrition. In: D'MELLO, J. P. D. (Ed.). Amino acid in farm animal nutrition. 2.ed. Wallingford: CAB International, p.143-155, 2003.

NASCIMENTO, T. M. T. et al. Apparent digestibility coefficients for amino acids of feed ingredients in tambaqui (Colossoma macropomum) diets. Revista Brasileira de Zootecnia, 49:e20190032, 2020.

NATIONAL RESEARCH COUNCIL - NRC. Nutrient requirements of fish and shrimp. National. Academy Press, DC, USA, 2011. 376p.

ROSTAGNO, R.S. et al. Tabelas brasileiras para aves e suínos: Composição de alimentos e exigências nutricionais. 3.ed. Viçosa: UFV, 2011. 252p.

SILVA, J. C. et al. Lysine requirement for tambaqui juveniles. Semina: Ciências Agrárias, 39(5):2157-2168, 2018.

SOUSA, T. J. R. et al. Phosporus requeriment of tambaqui fingerlings. Revista Caatinga, 32(3):795-804, 2019.

SOUZA, F. O. et al. Methionine plus cystine to lysine ratio in diets for tambaqui juveniles. Revista Caatinga, 32(1):243-250, 2019.

TANG, L. et al. Effect of methionine on intestinal enzymes activities, microflora and humoral immune of juvenile jian carp (Cyprinus carpio var. Jian). Aquaculture Nutrition, 15(5):477-483, 2009.

UNIVERSIDADE FEDERAL DE VIÇOSA - UFV. Sistemas de análises estatísticas e genéticas - SAEG. Versão 9.1. Viçosa, 2007. Available in: <https://arquivo.ufv.br/saeg>. Access in: September, 272021.

WANG, X. et al. Dietary methionine requeriment of the pre-adult gibel carp (Carassius auratus gibeilo) at a constant dietary cystine level. Aquaculture Nutrition, 22(3):509-516, 2016. 